\title{
How does adopting hybrid maize affect dietary diversity on family farms? Micro-evidence from Zambia
}

\author{
Melinda Smale ${ }^{1}$, Mourad Moursi ${ }^{2}$, and Ekin Birol ${ }^{3}$

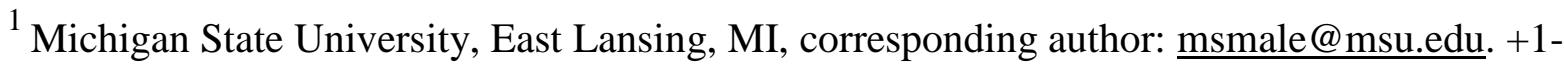 \\ 703-231-8492. \\ 2 International Food Policy Research Institute, Washington, DC. M.Moursi@cgiar.org \\ ${ }^{3}$ International Food Policy Research Institute, Washington, DC. E.Birol@cgiar.org
}

\begin{abstract}
Maize dominates as a staple food in Zambia, where the government has for many years promoted hybrid seed use in order to enhance the food self-sufficiency of poor rural families. Despite the policy importance of household nutrition in Zambia, we are not aware of any recent analyses that have related the use of hybrid seed to diets among smallholder maize growers. Previous research has demonstrated a linkage between indices of dietary diversity and healthy diets among women and children. We estimate two-stage, instrumental variables, Poisson, and ordered logit regression models to test the association between hybrid seed use and four indicators of dietary diversity: food group diversity (24-hour), vitamin A diversity (7-day), food frequency (7-day), and frequency of consuming foods fortified with vitamin A (7-day). Results are robust to econometric method and indicator: women interviewed in maize-growing households that plant hybrid seed have more diverse diets.
\end{abstract}

Keywords: Dietary diversity, Zambia, maize, hybrid seed 


\title{
How does hybrid maize use affect diet diversity on family farms? Micro-evidence from Zambia
}

\begin{abstract}
Maize dominates as a staple food in Zambia, where the government has for many years promoted hybrid seed use in order to enhance the food self-sufficiency of poor rural families. Despite the policy importance of household nutrition in Zambia, we are not aware of any recent analyses that have related the use of hybrid seed to diets among smallholder maize growers. Previous research has demonstrated a linkage between indices of dietary diversity and healthy diets among women and children. We estimate two-stage, instrumental variables, Poisson, and ordered logit regression models to test the association between hybrid seed use and four indicators of dietary diversity: food group diversity (24-hour), vitamin A diversity (7-day), food frequency (7-day), and frequency of consuming foods fortified with vitamin A (7-day). Results are robust to econometric method and indicator: women interviewed in maize-growing households that plant hybrid seed have more diverse diets.
\end{abstract}

Keywords: Dietary diversity, Zambia, maize, hybrid seed 


\section{INTRODUCTION}

Zambian smallholder farmers have grown hybrid maize since the 1970s, benefiting from public investments in maize research, two phases of state-managed subsidy programs, and one of the more vibrant seed industries in Eastern and Southern Africa (Howard and Mungoma 1997; Kassie et al. 2013). Despite this experience, surprisingly little research has been published on the impacts of hybrid maize until recently (e.g., Langyintuo and Mungoma 2008; Hamazakaza, Smale, and Kasalu 2013; Mason and Smale 2013).

Viewed from the perspective of the Green Revolution in wheat and rice in Asia (Gulati et al. 2004), some development practitioners have hypothesized that growing high-yielding crop varieties encourages crop specialization, and may drive farmers to abandon crops that serve as alternative food sources. Others have countered that adoption of high-yielding foodcrops in a land-constrained setting, such as hybrid maize in Malawi, enables farmers to allocate land away from their subsistence crop toward other food crops and remunerative cash crops (Heisey and Smale 1995). Compared to Malawi, Zambia's maize-based farming systems are land-abundant.

In a detailed study implemented by the International Food Policy Research Institute (IFPRI) during the late 1980s in the Eastern Province of Zambia, Kumar (1994) tested the relationship of hybrid seed use to dietary diversity among smallholder maize farmers. She concluded that while staple food consumption was greater in areas with higher rates of hybrid maize adoption, dietary diversity may have declined due to greater reliance by farmers on their own production and fewer purchased food types. Historically, maize-growing smallholders in Eastern Province, where Kumar conducted her research, grew hybrid maize for cash but continued to grow local maize varieties because of strong consumption preferences for flint-type 
grain. Thus, the negative relationship between hybrid maize adoption and food intake was a striking result.

The purpose of our analysis is to test the hypothesis that growing hybrid maize affects dietary diversity among smallholder maize-growing families in Zambia, with a particular focus on sources of vitamin A. We have no apriori reason for predicting the direction of effects. Growing hybrid seed could contribute to the diets of smallholder, maize-growing families in contradictory ways. On one hand, growing higher-yielding maize could enable smallholders to meet their staple food needs on smaller land areas, releasing land for the cultivation of other crops that can be consumed or sold. However, families with very limited land areas may simply consume more maize, adding to their caloric intake but not to dietary diversity. On the other hand, growing higher-yielding maize could lead to additional maize sales. Income earned form maize sales could enable farm families to purchase new foods, but these do not necessarily lead to more diverse diets. Devoting more land to hybrid maize because it is profitable might narrow the range of crops produced and consumed.

Malnutrition and food security continue to occupy the center stage of agricultural policy in Zambia. In our analysis, we also address a specific element of micro-nutrition-Vitamin A. Vitamin A deficiency is a cause of impaired growth, weakened immune systems, and increased risk of death due to infection among children (West 2002). In Zambia, over half of children under five years of age are considered to be vitamin A deficient, as indicated by low plasma retinol concentrations (NFNC/University of Zambia/MOST/CDC 2004).

Despite progress in supplementing the consumption of vitamin A through health programs and fortified sugar, vitamin A deficiency persists. Maize meal products are another means of fortifying food. However, although maize is the most commonly consumed food in 
Zambia, only 23 percent of households purchase pre-milled roller and breakfast maize - the only maize meal products that are considered to be fortifiable (Fiedler et al. 2012). Since most households rely on their own harvested grain or do not purchase fortifiable maize meal products, improved maize seed is a major vehicle for addressing vitamin A deficiency.

We test our hypothesis by applying econometric models to data collected through personal interviews with 1,128 maize-growing farm households in the major maize-producing regions of Zambia in 2011. We define dietary diversity indicators according to recent research advances (Arimond et al. 2010). We specify our estimating equation within the rubric of the nonseparable model of the household farm, and apply it with instrumental variables and ordered logit regressions.

\section{METHODS}

\subsection{Data sources}

The data were collected through face-to-face interviews in a statistical survey that was implemented by the International Maize and Wheat Improvement Center (CIMMYT), and the University of Zambia. The population domain included five provinces (Central, Copperbelt, Eastern, Lusaka, Northern, and Southern), located in three agroecological zones (AEZ I, AEZ IIA, and AEZ III) that represent the major maize-producing zones of Zambia). These three AEZs served as strata.

For reference purposes, AEZ I is a low-rainfall area that includes the southern portions of Southern and Western Provinces (Luanga-Rift Valley). This zone is the hottest and driest region of Zambia. AEZ IIA runs east to west across the center of the country and includes the Central 
and Lusaka provinces as well as parts of Southern and Eastern Province. Rainfall and soils are more favorable for farming, and the zone has also received more public investment in agriculture. AEZ III is a higher rainfall area that includes the Copperbelt, Luapula and NorthWestern Provinces, and is more densely populated and urbanized.

The total number of households in the sample was allocated proportionate to population and maize production (20 percent for AEZ I, 40 percent each for the other two zones). First-stage sampling units were standard enumeration areas (SEA). Numbering 113, these were selected with probability proportionate to size, by AEZ, from lists maintained by the Central Statistical Office.

The second-stage units were all households living in each SEA. SEAs may comprise more than one village. In each village within the selected SEA, survey team supervisors requested a full current list of farm households from the respective village head(s). If one village spanned more than one SEA, supervisors worked with the village heads to identify the households located within the boundaries of the selected SEA. Supervisors then combined the lists of all farm households across villages in the SEA to obtain one full list of households within the selected SEA.

Ten households were selected in each SEA by simple random sample drawn from a list. By design, data were self-weighted. The full sample consists of 1,128 households, of which only 19 cultivated more than 20 ha. These were eliminated in our analysis. In Zambia farmers cultivating less than 20 ha are defined as "smallholders." Data were collected by three survey teams, each including a supervisor and five enumerators, from June to August, 2011. Authors had access to household identification numbers, but not name lists. Data were made anonymous prior to analysis. 
We have also made use of secondary data sources for crop commodity prices. Districtlevel retail price data for key crops like maize, cotton, and sweet potato were obtained from the Central Statistical Office's Consumer Price Index database for the two years preceding the survey (2009-2010).

Pixel-level data on rainfall and soil quality were utilized in the analysis. Long-term average rainfall data for the period 1950-2000 were obtained from WorldClim, an online global climate database (Hijmans et al. 2005). Five-year average rainfall data were assembled from CPS Unified Global Daily Precipitation Analysis defined by Optimal Interpolation of gauge observations (Schneider et al. 2011). Short-term average rainfall data for the preceding year, 2010, were retrieved from the GPCC Full Data Product (V6), which is based on qualitycontrolled data from 67,200 stations worldwide. Information on soil nutrient availability was obtained from the Food and Agriculture Organization (FAO) (FAO/IIASA/ISRIC/ISSCAS/JRC 2009).

\subsection{Measurement of Dietary Diversity}

The prevalence and irreversible consequences of micronutrient malnutrition are well-known by researchers and governments. A decade ago, challenges associated with measuring nutrition with anthropometry and testing procedures in developing countries led to the development of indices of household dietary diversity using cost-effective survey instruments based on recall. Research implemented by IFPRI (e.g., Hoddinott and Yohannes 2002) confirmed that a more diversified diet is associated with improvement in nutritional parameters, including: birth weight; child anthropometric status; improved hemoglobin concentrations; caloric and protein adequacy; 
percentage of protein from animal sources (high quality protein); and per capita consumption (a proxy for household income). Studies that validated dietary diversity against nutrient adequacy in developing countries confirmed a positive relationship and a consistently positive association between dietary diversity and child growth (Ruel 2002; Arimond and Ruel 2003; Working Group on Infant and Young Child Feeding Indicators 2006; Moursi et al. 2008).

In an in-depth review of the literature on this topic, Ruel $(2002 ; 2003)$ concluded that although dietary diversity was universally recognized as a key component of healthy diets, there was a lack of consensus on how to operationalize this concept. Reference periods ranged from 1 to 15 days, and questions remained regarding the classification of foods by group, portion size and frequency of intake, scoring systems, cutoff points, and reference periods for recall.

In a widely-used approach documented by Swindale and Bilinsky (2006), the household dietary diversity score was operationalized as a count over 12 food groups consumed in either a 7-day or 24-hour reference period. To consider micronutrients, food groups were expanded and/or regrouped by micronutrient and counted.

Meanwhile, researchers had learned that inequitable intra-household distribution may prevent women's access to micronutrient-rich foods even when they are available. Typically, women's scores were found to be representative of their children's (Nguyen et al. 2013). Thus, in cases where the organization of the household and decision-making processes suggested that distributional considerations were likely to be remarkable, analysts proposed scores constructed on the basis of individual interviews. For example, individualized diversity scores were recommended in the case of polygamous or extended family groups, or when focusing specifically on the nutrition of women and children. 
Arimond et al. (2010) advanced dietary diversity research by assessing the performance of 8 candidate diversity indicators against the mean probability of adequacy for 11 micronutrients in 5 countries with poor populations. Findings confirmed the predictive strength for the diversity indicators, although the best performing indicator depended on the country context. Based on results, they recommended an indicator constructed on nine food groups: 1) all starchy staples; 2) all legumes and nuts; 3) all dairy and dairy products; 4) organ meat; 5) eggs; 6) flesh foods and other small animal protein; 7) vitamin A-rich, dark green leafy vegetables; 8) other vitamin-A rich vegetables and fruits, and 9) other fruits and vegetables. Fats and oils are an optional group that was excluded from their analysis. In the context of micronutrient analysis, fats and oils are considered as calories only.

The food group diversity indicator Arimond et al. (2010) recommend is based on 24-hour recall. This reference period has been shown to perform better when there was a minimum quantity of consumption required for a food group to "count" in the diversity score. In their analysis, Arimond et al. used data collected from individuals and set the minimum consumption cut off requirement at 15 grams. In other words, an individual had to consume at least 15 grams of meat in order for her to receive a count of +1 in the flesh food category.

The foregoing research led us to choose four diversity indicators for this analysis, each of which highlights a different aspect of consumption. We constructed the first indicator, which we refer to as "food group diversity," over ten groups. Enumerators elicited an inventory of food consumed from the primary female decisionmaker in the household with reference to the preceding 24-hour period. Groups were defined as: 1) starchy staples (maize, other cereals, sweet potato, other roots and tubers); 2) legumes and nuts (beans, groundnuts, other pulses); 3) dairy (milk, cheese); 4) organ meats (kidney, liver); 5) eggs; 6) flesh foods (fish, red meat, poultry); 7) 
vitamin A-rich fruits (mango, papaya, guava); 8) vitamin A-rich vegetables (green leafy vegetables, orange sweet potato); 9) other fruits and vegetables; 10) vitamin A-fortified foods (sugar, Blue Band margarine).

To reflect conditions specific to Zambia, we added a tenth group (fortified foods) to the 9 groups recommended by Arimond et al. (2010). In Zambia, all sugar is fortified with vitamin A. Sugar samples obtained during the HarvestPlus 24 hour recall survey showed that the median vitamin A content of fortified sugar was $8.8 \mathrm{mg} / \mathrm{kg}$ and $59 \%$ of samples contained at least the minimum recommended amount of $10 \mathrm{mg} / \mathrm{kg}$. Only $5 \%$ of sugar consumed was non-fortified. Thus, for the purposes of our analysis, we assumed all sugar to be fortified. The 10 groups were constituted from the 19 categories included in the survey instrument (See Appendix Table A.1) ${ }^{1}$.

Given the scale of the baseline survey and its multiple objectives, we were unable to collect data on quantities consumed in each category. We define vitamin A-rich foods as a "source" based on the Codex Alimentarius definition (60 Retinol Activity Equivalents (RAE) per $100 \mathrm{~g}$ of vitamin $\mathrm{A})^{2}$. We also utilized Hotz et al. (2002). The food group diversity indicator ranges in value from 1 to 10 .

Our second indicator is a count of the groups containing foods that are sources of vitamin A or beta-carotene, which we call "vitamin A diversity." Again, we based our construction on the original 19 groups in the survey instrument. In Zambia, food items rich in vitamin A include: orange-fleshed sweet potato; fruits, eggs, dairy products, dark-green leafy vegetables, red meat, organ meat, Blue Band margarine, and sugar (Appendix Table A.1). The vitamin A diversity

\footnotetext{
${ }^{1}$ Unfortunately in the survey instrument neither vegetables nor fruits were disaggregated as vitamin A rich vegetables/fruits and other vegetables/fruits. Such a disaggregation would have been ideal. However, the majority of the examples given for fruits were vitamin A rich fruits (with the exception of pineapple). In addition, in the original data, orange sweet potato was a separate category. According to the 24 hour recall data collected by HarvestPlus and published by Hotz (see reference above), the contribution of yellow and orange vegetables to vitamin A intake is very low in Zambia as these are consumed very infrequently and in small quantities.

${ }^{2}$ RAE differs from Retinol Equivalents (RE), which were common in older food composition tables. $S$
} 
indicator ranges from 0 to 9 . Both 24-hour and 7-day indicators were constructed, but the 7-day indicator was preferred for econometric analysis because it has a more normal distribution.

The third indicator we use is a "food frequency" index, constructed according to Arimond and Ruel (2002). One of the main limitations of the first two indicators is that neither takes into account consumption differences among households within a given food group. For example, one individual may have consumed meat three times during the reference period while another only ate it once, but both score +1 for meat consumption. Arimond and Ruel (2002) proposed that data collected for a seven-day recall period also account for the frequency of consumption. For each food group, a household or individual receives a score of 0 for frequencies fewer than four times per week, a score of unity for frequencies from 4 to 6 (inclusive) times per week, and a score of 2 for frequencies of seven or more. The diversity count is then summed across food groups. With ten groups, the hypothetical range of this indicator is considerably greater (1 to 20); in the data, the maximum is 17.

Our fourth indicator is the frequency of consuming vitamin A fortified foods, which include sugar and Blue Band margarine. Since these are costly consumption items, we hypothesize that the relationship of growing hybrid maize to this outcome variable could differ from that of the other indicators. We refer to this indicator as "vitamin A fortified food frequency." The indicator has only three values $(0,1 \text {, and } 2)^{3}$

\footnotetext{
${ }^{3}$ Since our analysis was conducted, the Global Dietary Diversity Indicator For Women has been published by the Food and Agriculture Organization of the UN (FAO) and the Food and Nutrition Technical Assistance III Project (FANTA). This indicator, which includes 10 food groups, is still under review. We computed the dietary diversity score using the 10 food group indicator and it did not alter any of our conclusions. Mean dietary diversity moved from 5.3 with the 9 food group indicator to 5.5 with the 10 food groups. This was due to the fact that beans and peas, which are now in a category of their own in the 10 food group indicator, are very infrequently consumed in Zambia.
} 


\subsection{Conceptual Framework}

The theory of the agricultural household (Singh, Squire, and Strauss 1986; de Janvry, Fafchamps, and Sadoulet 1991) provides the conceptual underpinning of our empirical strategy. According to this framework, the household combines farm resources and family labor to maximize utility over leisure and consumption goods produced on the farm or purchased on the market. Decisions regarding crop and variety choice are constrained by: a production technology, conditioned on the farm physical environment and land area; family labor time allocated to labor and leisure; and a full income constraint. The full income constraint stipulates that a season's expenditures of time and cash cannot exceed the sum of net farm earnings and income that is “exogenous" to crop and variety choices. In a single-period model, "exogenous" income includes stocks, remittances, pensions, and other transfers from the previous season.

The theory of the agricultural household is suitable for analyzing the decisions of farmers who are not fully commercialized and/or who operate with missing or imperfect markets. When markets are perfect and farmers are neutral to risk, consumption and production decisions are separable, and the model of the agricultural household simplifies to profit-maximization. Crop and variety choices are then based on relative prices and farm physical conditions.

Although there is considerable heterogeneity in the objectives pursued by Zambian maize growers, most of the smallholder famers interviewed in our survey do not operate in a context of perfectly functioning markets. Nor can we assume that they are neutral to risk. In this setting, consumption and production decisions are non-separable. Household characteristics that affect preferences and access to markets influence crop and variety choices. In this context, following the theoretical framework of the farm household, the prices actually faced by farmers are not 
market prices but shadow prices that reflect their household characteristics as well as market characteristics.

We follow Van Dusen and Taylor's (2005) adaptation of the household model to the analysis of crop diversity, applying it here to dietary diversity. Household utility is defined over the consumption of goods produced on the farm $(\mathbf{X})$ and all other purchased goods $(\mathbf{Z}$, with normalized price 1), given a vector of exogenous socioeconomic and household characteristics ( $\Phi$ hh). Households maximize utility subject to a full income constraint, where income includes farm income, exogenous income (Y ) and household labor (T) valued at the local market wage, w. Market constraints, represented by $\mathrm{H}(\cdot)$ are functions of exogenous factors ( $\boldsymbol{\Phi}$ farm). Households choose the level of production of $j$ crops, $j=1,2, \ldots \mathrm{J}$, denoted by $\mathbf{Q}_{\mathrm{j}}$. The cost function C (Q; $\mathbf{\Phi f a r m ) ~ i n c o r p o r a t e s ~ t h e ~ t e c h n o l o g i c a l ~ c o n s t r a i n t s ~ f o r ~ t h e ~ h o u s e h o l d , ~ w h e r e ~}$ Фfarm is a vector of exogenous farm characteristics. A diversity constraint $D(\cdot)$ defines the optimal bundle of food attributes or combination of foods consumed at the household level. Prices (p) are endogenous to the household and are, in turn, functions of household and market characteristics, as well as observed prices. These prices are also known as "effective" or “decision" prices because they determine farmer choice but their values are unobserved.

Following the agricultural household model as presented in Singh, Squire and Strauss (1986) and later by Van Dusen and Taylor (2005), the model can be expressed as follows:

$$
\begin{aligned}
& \operatorname{Max}_{\mathbf{x}, \mathbf{z}} \mathrm{U}\left(\mathbf{X}, \mathbf{Z} ; \boldsymbol{\Phi}_{\mathrm{hh}}\right) \\
& \mathbf{Z}=\mathbf{p} *(\mathbf{Q}-\mathbf{X})-\mathrm{C}\left(\mathbf{Q} ; \boldsymbol{\Phi}_{\text {farm }}\right)+\mathrm{Y}+\mathrm{wT}
\end{aligned}
$$

$$
\mathrm{H}\left(\mathbf{Q}, \mathbf{X} ; \boldsymbol{\Phi}_{\text {market }}\right)=0
$$




$$
\mathrm{D}=\mathrm{D}\left(\mathbf{Q}, \mathbf{X}, \mathbf{Z} ; \boldsymbol{\Phi}_{\text {market }}\right)
$$

The household chooses a vector of consumption levels $(\mathbf{X}, \mathbf{Z})$ such that the general solution to the maximization of household utility under binding constraints is a set of constrained optimal production levels optimal consumption levels $\mathbf{X c}, \mathbf{Z}$ :

$$
\begin{aligned}
& \mathbf{X}=\mathbf{X c}\left(\mathbf{p}, Y_{c}, \Phi_{\text {hh }}, \Phi_{\text {farm }}, \Phi_{\text {market }}\right) \\
& \mathbf{Z}=\mathbf{Z c}\left(\mathbf{p}, Y_{\mathrm{c}}, \boldsymbol{\Phi}_{\text {hh }}, \boldsymbol{\Phi}_{\text {farm }}, \boldsymbol{\Phi}_{\text {market }}\right)
\end{aligned}
$$

where Yc represents the full income for the constrained optimal production levels Qc.

The household's constrained dietary diversity outcome can be expressed in reduced form as indirect functions of price, income, household, farm and market parameters.

$$
\operatorname{Dc}=\operatorname{Dc}\left(\mathbf{X c}_{\mathbf{c}}, \mathbf{Z c}\left(\mathbf{p}, \mathrm{Yc}, \boldsymbol{\Phi}_{\text {hh }}, \boldsymbol{\Phi}_{\text {farm }}, \boldsymbol{\Phi}_{\text {market }}\right)\right) .
$$

Embedded in our production technology $\boldsymbol{\Phi}_{\text {farm }}$ is the variable $\boldsymbol{\tau}$, which indicates use of hybrid seed in maize production.

\subsection{Empirical Strategy}


Our regression model is a reduced form equation that relates hybrid seed use and other explanatory factors to dietary diversity among maize-growing farm households in Zambia. Following equation (7), the reduced form equation is rewritten as:

$$
\boldsymbol{Ð}_{\mathrm{i}}=\beta_{0}+\boldsymbol{\beta}_{\mathbf{1}} \mathbf{V}_{\mathbf{i}}+\boldsymbol{\beta}_{\mathbf{2}} \tau_{\mathbf{i}}+\boldsymbol{\varepsilon}_{\mathbf{i}} \quad \mathrm{i}=1, . ., \mathrm{N}
$$

Where $\mathbf{Ð}$ expresses dietary diversity in operational terms, $\mathbf{V}$ is a vector of exogenous explanatory variables, $\boldsymbol{\varepsilon}$ is the random error term, and $i$ indexes households. The variable $\boldsymbol{\tau}$ indicates use of hybrid seed in maize production, introduced explicitly to test the hypothesis of interest. Following the theory of the agricultural household, we control for household, farm, and market characteristics, including observed prices, among exogenous variables. Instead of observed, full income, we use value of assets, which represents longer-term income and is included in in vector V.

It is possible that our variable of interest, $\boldsymbol{\tau}$ (hybrid seed use), is endogenous due to measurement error, simultaneity, or selection bias. That is, the unobserved factors that predict the dietary diversity indicators might be correlated with the household's decision to grow hybrid seed. In that case, estimating equation (8) would result in biased estimates, overstating the impacts of hybrid seed use on dietary diversity.

Thus, we estimate the model via two-stage least squares equation, with a binary variable measuring hybrid seed use in the first stage even though the assumed model is linear. Angrist and Krueger (2001) state that even in the case of a dichotomous variable in the first of the two equations, a two-stage least squares equation produces consistent estimators that are less sensitive to assumptions about functional form. They advocate this approach over use of 
nonlinear models such as probit or logit. A two-stage least squares equation, which relies on the central limit theorem, is considered to be robust; even with a dummy endogenous variable, second stage estimates are consistent.

Using standard model diagnostics for the instrumental variables, a two-stage least squares regression include tests of (a) the relevance of the instrument set; (b) model identification; and (c) endogeneity of the adoption variable. Model diagnostics include i) the evaluation of the joint F-test for excluded instruments in the first stage regression; ii) the Chi-squared test with the Anderson canonical correlation coefficient; and iii), the Chi-squared test with the Sargan statistic. A rejection of the null hypotheses in the Anderson test indicates that the matrix is full column rank (the model is identified). Failure to reject the null hypothesis in the Sargan test indicates that the "extra" instrumental variables are exogenous in the structural equation, supporting the validity of the instruments.

As a robustness check, to validate our regression results based on the binary variable, we also test the endogeneity of hybrid seed quantities (kilograms-kg) planted in each outcome equation. This enables us to associate the scale of hybrid seed use with diversity indicators. We apply ordered logit regression to test hypotheses concerning the fourth indicator, which has three outcomes that are ordinal and ordered (from less frequent to more frequent, where more frequent is hypothesized to be "better").

Definitions of explanatory variables are shown in Table 1, along with summary statistics. Literacy, defined as ability to read (or both read and write, as self-reported) is a household characteristic that is related to knowledge about hybrid seed. We also expect that it is related to 
Table 1: Definition of Explanatory Variables and Summary Statistics

\begin{tabular}{|c|c|c|c|}
\hline Variable & Construction & Mean & St. Dev. \\
\hline \multicolumn{4}{|l|}{ Potentially endogenous } \\
\hline Use hybrid seed & 1 if grow hybrid maize in survey year, 0 & 0.68 & 0.014 \\
\hline Hybrid seed planted & $\begin{array}{l}\text { Total kg planted in survey year, named F1 } \\
\text { hybrid }\end{array}$ & 18.5 & 38.1 \\
\hline \multicolumn{4}{|l|}{ Explanatory variables } \\
\hline Female headship & $\begin{array}{l}\text { Day-to-day household head female }=1,0 \\
\text { else }\end{array}$ & 0.192 & 0.394 \\
\hline Literacy & $\begin{array}{l}\text { Number of literate members (read or read } \\
\text { and write) divided by household size }\end{array}$ & 0.538 & 0.270 \\
\hline Young adults & Number of adults aged 14 through 18 & 1.06 & 1.11 \\
\hline Mature adults & Number of adults aged 19 through 45 & 2.09 & 1.29 \\
\hline Older adults & Number of adults aged 46 or over & 0.92 & 0.93 \\
\hline Land size & $\begin{array}{l}\text { Total land cultivated in major and minor } \\
\text { seasons (ha) divided by household size }\end{array}$ & 0.43 & 0.42 \\
\hline Assets & $\begin{array}{l}\text { Logarithm of total value of farm equipment } \\
\text { and structures, livestock, and other } \\
\text { household assets such as transport } \\
\text { equipment and savings (ZMK) }\end{array}$ & 16.65 & 1.51 \\
\hline Cell & Own cellphone $=1 ; 0$ else & 0.695 & 0.461 \\
\hline Radio & Own radio $=1 ; 0$ else & 0.770 & 0.421 \\
\hline Distance to paved road & $\begin{array}{l}\text { Euclidean distance from household to paved } \\
\text { road in meters }\end{array}$ & 39060 & 52703 \\
\hline Seed-to-grain price & $\begin{array}{l}\text { Ratio of farm-gate, } \mathrm{kg} \text {-weighted average } \\
\text { seed price in } 2010 \text { to district mean maize } \\
\text { grain price (per } \mathrm{kg} \text { ) in } 2009\end{array}$ & 9.05 & 3.83 \\
\hline Bean price & District mean bean price $2009-10$ & 3516 & 954.9 \\
\hline Cotton price & District mean cotton price $2009-10$ & 1817 & 398.2 \\
\hline Sweet potato price & District mean sweet potato price $2009-10$ & 520 & 180.8 \\
\hline LT rainfall & Long-term average rainfall (mm) & 985 & 177.7 \\
\hline 5-year rainfall & 5-year average rainfall $(\mathrm{mm})$ & 729 & 55.0 \\
\hline Planting rainfall & Rainfall in October 2010 & 5.36 & 7.07 \\
\hline Nutrient availability & $\begin{array}{l}\text { Index for soil texture, soil organic carbon, } \\
\text { soil } \mathrm{pH} \text {, total exchangeable bases }\end{array}$ & 2.15 & 0.758 \\
\hline \multicolumn{4}{|l|}{ Instrumental variables } \\
\hline Receive subsidy & $\begin{array}{l}\text { Received subsidized seed from Farm Input } \\
\text { Support Programme (FISP) in } 2010 \text { (1=yes, } \\
0 \text { else) }\end{array}$ & 0.654 & 0.476 \\
\hline FISP seed & Hybrid seed received from FISP $(\mathrm{kg})$ & 11.4 & 18.5 \\
\hline Association frequency & $\begin{array}{l}\text { Number of registered associations per ton of } \\
\text { maize produced in district }\end{array}$ & 4.18 & 2.87 \\
\hline
\end{tabular}

Notes: ZMK=Zambian Kwacha

Source: Authors. 
food consumption and possibly to dietary diversity. We measure this proxy for human capital as the total number of literate persons per household, which averages 3.7 across the full sample. Mean household size is 6.9 , by comparison. We also control for female headship, defined in terms of involvement in day-to-day decision-making. About 20 percent of households in the sample are de facto female-headed.

Potential labor constraints are expressed in terms of the number of young, mature, and older adults in the household, counted as separate factors. Measuring these groups separately enables us to differentiate effects according to age group, which we could not accomplish if these were combined in a single variable. Other asset endowments include land resources, measured as the total area cultivated in both preceding (major and minor) seasons per capita, to ensure exogeneity. Total land area to which households had access had a large number of missing observations, and enumerators sensed that farmer estimates were relatively unreliable. No land markets or land rental markets are yet apparent in the survey zones, where usufruct continues to rely on customary norms.

In this cross-sectional, single-year survey, we have measured expenditures and income but these cannot be considered as exogenous to dietary diversity. As Yc, we employ total assets, which is a measure of longer-term income. We use the natural logarithm of asset values because of the skewness in their distribution. The amount of credit received was non-zero in only 21 cases and was not included as a separate indicator of financial capital.

Prices and market services include the seed-to-grain price ratio, hypothesized to be a major determinant of the commercial demand for seed (Heisey et al. 1998; Smale and Olwande 2014). Market access is expressed as the distance to the nearest paved road. Seed-to-grain price ratios were calculated as the kilogram-weighted average cost per kilogram of seed planted by the 
farmer, divided by the district-average maize price in the preceding season. Prices in the current season would not have been known at the time of planting. Fertilizer prices were not entered because data were sparser, measured by unit of volume rather than nutrients, and highly correlated with seed and maize prices. Bean, cotton, and sweet potato prices are included as potential output complements or substitutes, also expressed as district means in the preceding season. Prices were not collected in the survey, as explained under data sources. Cell phone and radio ownership measure access to market information services.

Broadly speaking, the natural capital of the household is strongly influenced by the agroclimatic and farming conditions of the area. Of the variables included in the data we consulted (see section 2), we calculated the long-term (50 year) average and the five-year average. We interpret the long-term average as controlling for essential features of the agroecology that are relatively immutable. The five-year average represents the decision-making history of greatest relevance to the farmer, because it lies within memory. We also include the rainfall measured at the planting time. In terms of soil variables, all we examined (nutrient retention capacity, rooting conditions, oxygen availability to roots, excess salts, toxicity, workability, acidity) were highly correlated with nutrient availability. We included only nutrient availability in the regressions. The rating system for nutrient availability uses three diagnostic factors from the top 30 centimeters $(\mathrm{cm})$ of the soil. These factors include organic carbon (percent), base saturation (percent), and soil reaction $(\mathrm{pH})$. Numeric values assigned to factor ratings according to the degree of limitations are reported in the Appendix (Table A.2).

We employ three instrumental variables. In the regressions testing the endogeneity of the binary variable for hybrid seed use in dietary diversity outcomes, we use a binary variable expressing whether or not the farm household was a beneficiary of the Farm Input Support 
Programme (FISP). Preliminary regressions resulted in failure to reject the hypothesis that FISP participation is a recursive determinant of hybrid seed use. FISP orders are placed before the planting period. In turn, FISP participation can only affect dietary diversity after the harvest through its impact on maize productivity as a consequence of planting hybrid seed and applying fertilizer. The amount of FISP seed received is used as the (second) instrumental variable in scale of hybrid use equations.

The third instrumental variable is the frequency of registered associations per $10,000 \mathrm{~kg}$ of maize produced, also measured at the district scale of observation. This variable expresses the density of associations that qualify for FISP benefits. Our hypothesis is that the greater this density, the more likely any individual household is to receive subsidized seed (and fertilizer).

Separate regressions were estimated for each outcome variable of interest. As explained in the methods section, outcome variables include four dietary diversity scores: 1) the 24-hour household dietary diversity score; 2) the 7-day vitamin-A dietary diversity score; 3) the food frequency score; and 4) vitamin A fortified food frequency.

\section{RESULTS AND DISCUSSION}

\subsection{Descriptive Statistics}

Table 2 shows the percentage of respondents who reported consuming foods classified among the ten groups used to construct the individual dietary diversity score, considering all households and comparing those who grow maize hybrids with those who do not. As noted above, in accordance with recent research on measuring dietary diversity, to represent the consumption of 
women and their children, enumerators elicited an inventory of food consumed from the primary female decisionmaker in the household with reference to the preceding 24-hour period.

Table 2. Comparison of Food Groups Consumed in 24 hours Preceding Survey, by Use of Maize Hybrids

\begin{tabular}{|c|c|c|c|c|}
\hline & \multicolumn{2}{|c|}{ Grow maize hybrids } & \multirow{2}{*}{$\begin{array}{l}\text { All } \\
\text { farmers }\end{array}$} & \multirow{2}{*}{$\begin{array}{c}\mathrm{P}- \\
\text { value* }\end{array}$} \\
\hline & No & Yes & & \\
\hline Starchy staples & 86.9 & 90.8 & 89.5 & 0.0550 \\
\hline Nuts and legumes & 71.2 & 73.3 & 72.6 & 0.4810 \\
\hline Dairy & 16.3 & 25.3 & 22.4 & 0.0010 \\
\hline Organ meats & 2.6 & 6.1 & 5.0 & 0.0150 \\
\hline Eggs & 17.2 & 24.1 & 21.9 & 0.0100 \\
\hline $\begin{array}{l}\text { Flesh foods and } \\
\text { other small animal } \\
\text { protein }\end{array}$ & 45.6 & 57.7 & 53.8 & 0.0000 \\
\hline $\begin{array}{l}\text { Vit A rich dark } \\
\text { green leafy }\end{array}$ & & & & \\
\hline $\begin{array}{l}\text { vegetables } \\
\text { Other Vit A rich } \\
\text { fruits and }\end{array}$ & 20.3 & 25.8 & 24.0 & 0.0530 \\
\hline vegetables & 85.2 & 89.4 & 88.0 & 0.0470 \\
\hline $\begin{array}{l}\text { Other fruits and } \\
\text { vegetables }\end{array}$ & 82.6 & 83.2 & 83.0 & 0.7950 \\
\hline $\begin{array}{l}\text { Vit A fortified } \\
\text { foods }\end{array}$ & 58.7 & 72.0 & 67.8 & 0.0000 \\
\hline
\end{tabular}

As would be expected, the most frequently consumed items were starchy staples, consisting predominantly of maize but including other cereals. Other vitamin A-rich fruits and vegetable were next in order of importance. These include pumpkin, tomatoes, mango, and papaya, items that are more likely to be consumed in one season than another and in relatively small quantities as ingredients in stews or as snacks. Other fruits and vegetables were also consumed often by respondents interviewed. Nuts and legumes were next in order of overall frequency, mostly reflecting the consumption of groundnuts. Vitamin A-fortified foods 
(primarily sugar) were consumed by over two-thirds (68 percent) of women interviewed in the previous 24 hours. Dark green leafy vegetables were consumed by nearly one quarter of respondents (24 percent). Again, consumption of this last group is seasonal. Flesh foods, including red meat, poultry, and fish (fresh or dried), were consumed by over half (53.8 percent). Less frequently consumed food groups included dairy products (22 percent), eggs (22 percent), and organ meats (5 percent).

At significance values of 5 percent or less, women and children in households growing hybrid maize were more likely to have consumed foods classified in any of the food groups, with the exception of other fruits and vegetables and nuts and legumes. Bivariate relationships are strongest for foods containing large amounts of protein, such as dairy products, flesh foods, eggs, or organ meats, but these are also highly significant for the group containing food that is fortified in vitamin A (sugar, Blue Band margarine).

Mean scores for all four diversity indicators are shown in Table 3, comparing users of F1 hybrid maize seed and non-users across the entire sample of maize-growing households. Of 10 food groups compiled from the 19 included in the survey, women in households growing maize hybrids consumed a mean of 5.5 in a 24-hour period, compared with a mean of 4.9 among nonusers. Vitamin A diversity was also higher among women in hybrid seed-grain maize growers, averaging 4.1 out of a total of 9 groups, compared to 3.6 among farmers who did not grow hybrids. Mean food frequency was 8.3 among hybrid maize growers and only 7.5 among non- 
Table 3. Comparison of Mean Values of Dietary Diversity Indicators, by Use of Maize Hybrids

\begin{tabular}{lcccr}
\hline & Vitamin & & $\begin{array}{c}\text { Vitamin A } \\
\text { Fortified } \\
\end{array}$ \\
& $\begin{array}{c}\text { Food Group } \\
\text { Diversity }\end{array}$ & $\begin{array}{c}\text { A } \\
\text { Diversity }\end{array}$ & $\begin{array}{c}\text { Food } \\
\text { Frequency }\end{array}$ & $\begin{array}{c}\text { Food } \\
\text { Frequency }\end{array}$ \\
\hline $\begin{array}{l}\text { Grow maize } \\
\text { hybrids }\end{array}$ & & & & \\
\multicolumn{1}{c}{ No } & 4.87 & 3.56 & 7.45 & 0.901 \\
$\quad$ Yes & 5.48 & 4.13 & 8.28 & 1.17 \\
All maize growers & 5.28 & 3.95 & 8.01 & 1.09 \\
P-value, t-test & 0.0000 & 0.0000 & 0.0000 & 0.0000 \\
\hline
\end{tabular}

Source: Authors. T-tests compare means between hybrid and non-hybrid growers.

growers. Both of these scores are less than half the hypothetical maximum of 20 for this indicator, which demonstrates that considering the frequency of consumption has a dampening effect on dietary diversity. Finally, the frequency of consumption of foods fortified with vitamin A is also greater among women and children in households growing hybrid maize.

Thus, descriptive statistics support the hypothesis that hybrid seed use and dietary diversity are positively related. However, bivariate analysis can obscure the relationship between the two variables given the presence of other underlying factors that influence both. Next, we test this hypothesis econometrically using multivariate analysis and testing for endogeneity of hybrid seed use with instrumental variables.

\subsection{Econometric Results}

Diagnostic tests performed with instrumental variables regression result in failure to reject the hypothesis that growing hybrid maize is exogenous in household dietary diversity, vitamin A 
diversity, or food frequency. Only in the model testing the impact of the amount of hybrid seed planted on the frequency of consuming foods fortified with vitamin $\mathrm{A}$ is the hypothesis of exogeneity rejected. The null hypothesis of homoskedasticity could not be rejected in any of the regressions. Other tests support the identification of hybrid seed use and validity of the instruments, and the null hypothesis of homoscedasticity could not be rejected in any of the regressions (Table 4).

As a consequence of diagnostic tests, we estimated all regressions with the binary variable for hybrid seed use using ordinary least squares (OLS). Recognizing potential clustering effects of households due to the sample design, robust standard errors were estimated with village clustering. Regression coefficients and robust standard errors are shown in Table 5.

Growing hybrid seed is associated with greater food group diversity (at 1 percent significance), and also with a score that is 0.34 points higher, on average. Higher asset values, which are strongly correlated with land size, cell phone and radio ownership, which provide less costly access to information, and adult literacy are strongly associated with more diverse diets. Higher long-term rainfall, higher rainfall over the 5 years preceding the survey, and greater availability of nutrients in the soil is positively associated with this outcome. These findings possibly reflect the fact that cropping systems with more fertile soils and moisture contribute to the capacity of farm families to produce a broader range of crops. Distance to paved roads has a strongly negative impact on food group diversity, supporting the notion that farm families with greater access to markets have the potential to both diversity crops profitably and to purchase foods they do not produce for themselves. Positive associations with cotton prices are consistent with this hypothesis as well, since cotton is a cash crop. 
Table 4. Diagnostic Tests, Instrumental Variables Regressions

\begin{tabular}{|c|c|c|c|}
\hline Test & $\begin{array}{c}\text { Food Group } \\
\text { Diversity }\end{array}$ & Vitamin A Diversity & Food Frequency \\
\hline \multicolumn{4}{|l|}{ Grow hybrid } \\
\hline F-test & 62.6 & 62.6 & 62.6 \\
\hline (instruments) & $(0.000)$ & $(0.000)$ & $(0.000)$ \\
\hline Anderson statistic (Chi- & 113 & 113 & 113 \\
\hline squared) & $(0.000)$ & $(0.000)$ & $(0.000)$ \\
\hline Sargan statistic & 0.114 & 1.67 & 0.182 \\
\hline (Chi-squared) & $(0.736)$ & $(0.197)$ & $(0.669)$ \\
\hline Pagan-Hall & 24.2 & 29.8 & 38.4 \\
\hline (Chi-squared) & $(0.234)$ & $(0.717)$ & $(0.790)$ \\
\hline Wu-Hausman & 0.212 & 0.304 & 0.139 \\
\hline$(\mathrm{F}$-test $)$ & $(0.645)$ & $(0.582)$ & $(0.709)$ \\
\hline \multicolumn{4}{|l|}{ Kg hybrid seed } \\
\hline F-test & 7.23 & 7.23 & 7.23 \\
\hline (instruments) & $(0.008)$ & $(0.008)$ & $(0.008)$ \\
\hline Anderson statistic & 14.5 & 14.5 & 14.5 \\
\hline (Chi-squared) & $(0.007)$ & $(0.007)$ & $(0.007)$ \\
\hline Sargan statistic & 0.299 & 0.001 & 0.371 \\
\hline (Chi-squared) & $(0.585)$ & $(0.973)$ & $(0.5424)$ \\
\hline Pagan-Hall & 18.615 & 7.66 & 31.11 \\
\hline (Chi-squared) & $(0.547)$ & $(0.9939)$ & $(0.537)$ \\
\hline Wu-Hausman & 0.0210 & 6.15 & 0.566 \\
\hline$($ F-test $)$ & $(0.647)$ & $(0.013)$ & $(0.452)$ \\
\hline
\end{tabular}

Source: Authors. Value of test-statistic (P-value). Note that the instrument tests are identical across models because the first-stage regression is the same in each set.

Findings with respect to diversity in sources of vitamin A are similar, although the impact of growing hybrid seed is even larger in magnitude (0.38). Literacy is not statistically significant in this regression, and a greater number of older adults in the household is negatively associated with vitamin A diversity, although the effect is statistically weak. This result may reflect the lifecycle stage of the household or a greater number of adult dependents. Total land area, including both rainy and dry seasons, in addition to assets and ownership of a cell phone and radio, is a 
Table 5. Impact of Growing Hybrid Maize Seed on Dietary Diversity

\begin{tabular}{|c|c|c|c|}
\hline & Food Group Diversity & Vitamin A Diversity & Food Frequency \\
\hline \multirow[t]{2}{*}{ Grow hybrid } & $0.344 * * *$ & $0.379 * * *$ & $0.314^{*}$ \\
\hline & $(0.109)$ & $(0.103)$ & $(0.183)$ \\
\hline \multirow[t]{2}{*}{ Female headship } & 0.0985 & -0.0219 & 0.317 \\
\hline & $(0.125)$ & $(0.119)$ & $(0.211)$ \\
\hline \multirow[t]{2}{*}{ Literacy } & $0.450 * *$ & 0.314 & $1.151 * * *$ \\
\hline & $(0.202)$ & $(0.194)$ & $(0.327)$ \\
\hline \multirow[t]{2}{*}{ Young adults } & -0.00290 & 0.0457 & 0.0180 \\
\hline & $(0.0499)$ & $(0.0470)$ & $(0.0778)$ \\
\hline \multirow[t]{2}{*}{ Mature adults } & 0.0224 & 0.0485 & 0.0175 \\
\hline & $(0.0413)$ & $(0.0368)$ & $(0.0735)$ \\
\hline \multirow[t]{2}{*}{ Older adults } & -0.00952 & $-0.0891 *$ & -0.0463 \\
\hline & $(0.0506)$ & $(0.0515)$ & $(0.0897)$ \\
\hline \multirow[t]{2}{*}{ Land size } & 0.164 & $0.407 * * *$ & $0.498 * *$ \\
\hline & $(0.134)$ & $(0.154)$ & $(0.235)$ \\
\hline \multirow[t]{2}{*}{ Assets } & $0.151 * * *$ & $0.0824 * *$ & $0.287 * * *$ \\
\hline & $(0.0348)$ & $(0.0359)$ & $(0.0605)$ \\
\hline \multirow[t]{2}{*}{ Cell } & $0.345^{* * *}$ & $0.384 * * *$ & $1.083 * * *$ \\
\hline & $(0.124)$ & $(0.102)$ & $(0.195)$ \\
\hline \multirow[t]{2}{*}{ Radio } & $0.360 * * *$ & $0.324 * * *$ & 0.216 \\
\hline & $(0.124)$ & $(0.113)$ & $(0.210)$ \\
\hline \multirow[t]{2}{*}{ Distance to paved road } & $-3.64 \mathrm{e}-06^{* * *}$ & $-2.02 \mathrm{e}-06^{* *}$ & $-5.14 \mathrm{e}-06 * * *$ \\
\hline & $(1.17 \mathrm{e}-06)$ & $(9.13 e-07)$ & $(1.84 \mathrm{e}-06)$ \\
\hline \multirow[t]{2}{*}{ Seed-to-grain price } & 0.0219 & 0.00795 & $0.0436^{*}$ \\
\hline & $(0.0135)$ & $(0.0130)$ & $(0.0260)$ \\
\hline \multirow[t]{2}{*}{ Bean price } & $4.51 \mathrm{e}-05$ & $-0.000103^{*}$ & $0.000281^{* *}$ \\
\hline & $(6.87 e-05)$ & $(6.09 \mathrm{e}-05)$ & $(0.000116)$ \\
\hline \multirow[t]{2}{*}{ Cotton price } & $0.000425^{* *}$ & $0.000475 * * *$ & $0.000658^{* *}$ \\
\hline & $(0.000174)$ & $(0.000149)$ & $(0.000282)$ \\
\hline \multirow[t]{2}{*}{ Sweet potato price } & 0.000490 & 0.000435 & 0.000677 \\
\hline & $(0.000298)$ & $(0.000309)$ & $(0.000572)$ \\
\hline \multirow[t]{2}{*}{ LT rainfall } & $0.00150 * * *$ & $0.00111 * * *$ & $0.00371 * * *$ \\
\hline & $(0.000455)$ & $(0.000404)$ & $(0.000765)$ \\
\hline \multirow[t]{2}{*}{ 5-year rainfall } & $0.00301 *$ & $-0.00260 * *$ & $0.00661 * *$ \\
\hline & $(0.00156)$ & $(0.00126)$ & $(0.00261)$ \\
\hline \multirow[t]{2}{*}{ Planting season } & 0.000836 & $-0.0205 * *$ & -0.00942 \\
\hline & $(0.0102)$ & $(0.00858)$ & $(0.0183)$ \\
\hline \multirow[t]{2}{*}{ Nutrient availability } & $0.121 *$ & $0.147 * *$ & 0.0524 \\
\hline & $(0.0685)$ & $(0.0651)$ & $(0.124)$ \\
\hline \multirow[t]{2}{*}{ Constant } & $-3.533 * * *$ & 1.266 & $-10.09 * * *$ \\
\hline & $(1.256)$ & $(1.147)$ & $(2.219)$ \\
\hline R-squared & 0.190 & 0.144 & 0.242 \\
\hline
\end{tabular}

Source: Authors. $\mathrm{N}=1045$. Robust standard errors in parentheses. $* * * \mathrm{p}<0.01, * * \mathrm{p}<0.05, * \mathrm{p}<0.1$ 
significant factor with a relatively large coefficient (0.41). Vitamin A diversity is greater in locations with lower five-year rainfall and less abundant planting rains in 2010, although longterm average rainfall counteracts this effect. Inspection of the underlying data shows that in the southern agroecological zone, which is drier, households were more likely to consume orange sweet potato, organ and flesh meats, and dairy products but not vegetable-based sources of vitamin A. Nutrient availability in the soils also has a positive effect. Lack of market access also depresses diversity of sources of vitamin A. Higher bean prices are negatively associated with vitamin A diversity, but the influence of cotton prices remains positive. The coefficients on price are also positive in this regression, and orange sweet potato is a source of vitamin A. Although the count of food groups is similar between the food group diversity and vitamin A diversity, the reference period is only 24 hours for food group diversity and 7 days for vitamin A diversity.

The dependent variables in the first two impact regressions shown in Table 5 reflect the incidence of consumption across food groups within a specified reference period. As expected, considering food frequency reduces the overall impact of growing hybrid seed on dietary diversity (coefficient of 0.32). Other results in this model are similar to those reported in the first two models. Total land area cultivated across both growing seasons is also significant, with larger magnitude (0.50). The effect of literacy is strongest in this regression, as is the effect of assets. Distance to paved roads has a more pronounced, negative influence on dietary diversity when consumption frequencies are taken into account. Higher rainfall in the preceding five seasons, as well as more rainfall over the long run, positively influences the frequency of consuming foods from more diverse groups. Nutrient availability is not statistically significant in this regression. These findings highlight the importance of considering various, comparative definitions for diversity measurement before drawing policy conclusions. 
Across the three diversity outcomes, almost identical results were obtained with the model testing the effect of the scale of hybrid seed use (kgs planted) rather than the binary $(0,1)$ adoption variable (Table 6). The regression model for vitamin A diversity was estimated with two-stage least squares because we failed to reject the exogeneity of hybrid seed quantities planted in the first-stage regression (see Table 4 for that result). The estimated size of the average effect of growing $10 \mathrm{~kg}$ of hybrid seed (the size of the FISP package in the survey year) on food group diversity is 0.04 units, which is small compared to that associated with growing hybrid maize at all (the binary variable). The magnitude of the coefficient for vitamin A diversity is 0.03 by comparison. Unexpectedly, the size of the coefficient is greatest when the frequency of consuming foods from the ten groups is considered $(0.05$ per $10 \mathrm{~kg}$ of hybrid maize seed planted). Most importantly, a greater scale of hybrid maize production is associated with more food group diversity (at 1 percent significance), more vitamin A diversity (at 5 percent significance), and a higher frequency of consuming foods from more diverse food groups (at 5 percent significance).

Results of the ordered logit regression testing the impacts of growing hybrid seed on the frequency of consuming food that is fortified with vitamin A (sugar and Blue Band margarine) are shown in Table 7 . The values of the dependent variable are $(0,1,2)$. Planting hybrid maize seed, but not the amount of seed planted, has an observable impact on consumption from these food groups (the p-value for the binary variable is 0.11 ). As with the other dietary diversity indicators, higher asset values, cell phone and radio ownership, adult literacy, and higher longterm rainfall play positive roles in consumption of these items, which are luxury goods. Higher seed-to-grain price ratios are positively associated with their consumption, perhaps reflecting more commercially oriented farming districts. Cotton prices again exert a positive influence, 
Table 6. Impacts of Scale of Hybrid Use on Dietary Diversity

\begin{tabular}{|c|c|c|c|}
\hline & Food Group Diversity & Vitamin A Diversity & Food Frequency \\
\hline \multirow[t]{2}{*}{ Hybrid seed planted (kg) } & $0.00397 * * *$ & $0.0317 * *$ & $0.00476^{* *}$ \\
\hline & $(0.00120)$ & $(0.0134)$ & $(0.00217)$ \\
\hline \multirow[t]{2}{*}{ Female headship } & 0.111 & 0.0801 & 0.332 \\
\hline & $(0.126)$ & $(0.145)$ & $(0.212)$ \\
\hline \multirow[t]{2}{*}{ Literacy } & $0.504 * *$ & $0.454 * *$ & $1.204 * * *$ \\
\hline & $(0.202)$ & $(0.226)$ & $(0.324)$ \\
\hline \multirow[t]{2}{*}{ Young adults } & -0.00660 & -0.0207 & 0.0120 \\
\hline & $(0.0507)$ & $(0.0596)$ & $(0.0782)$ \\
\hline \multirow[t]{2}{*}{ Mature adults } & 0.00172 & -0.0839 & -0.00585 \\
\hline & $(0.0428)$ & $(0.0701)$ & $(0.0739)$ \\
\hline \multirow[t]{2}{*}{ Older adults } & -0.0187 & $-0.155 * *$ & -0.0570 \\
\hline & $(0.0514)$ & $(0.0674)$ & $(0.0900)$ \\
\hline \multirow[t]{2}{*}{ Land size } & 0.0579 & -0.445 & 0.371 \\
\hline & $(0.140)$ & $(0.386)$ & $(0.237)$ \\
\hline \multirow[t]{2}{*}{ Assets } & $0.147 * * *$ & 0.00840 & $0.280 * * *$ \\
\hline & $(0.0347)$ & $(0.0527)$ & $(0.0609)$ \\
\hline \multirow[t]{2}{*}{ Cell } & $0.387 * * *$ & $0.375 * * *$ & $1.119 * * *$ \\
\hline & $(0.124)$ & $(0.130)$ & $(0.195)$ \\
\hline \multirow[t]{2}{*}{ Radio } & $0.384 * * *$ & $0.306^{* *}$ & 0.237 \\
\hline & $(0.124)$ & $(0.138)$ & $(0.209)$ \\
\hline \multirow[t]{2}{*}{ Distance to paved road } & $-3.27 \mathrm{e}-06 * * *$ & $2.70 \mathrm{e}-07$ & $-4.73 e-06 * *$ \\
\hline & $(1.18 \mathrm{e}-06)$ & $(1.49 \mathrm{e}-06)$ & $(1.83 \mathrm{e}-06)$ \\
\hline \multirow[t]{2}{*}{ Seed-to-grain price } & $0.0223 *$ & -0.0225 & $0.0426^{*}$ \\
\hline & $(0.0135)$ & $(0.0211)$ & $(0.0257)$ \\
\hline \multirow[t]{2}{*}{ Bean price } & $5.05 e-05$ & $-0.000124 *$ & $0.000285^{* *}$ \\
\hline & $(6.91 \mathrm{e}-05)$ & $(7.03 \mathrm{e}-05)$ & $(0.000115)$ \\
\hline \multirow[t]{2}{*}{ Cotton price } & $0.000449 * *$ & $0.00119 * * *$ & $0.000708 * *$ \\
\hline & $(0.000176)$ & $(0.000379)$ & $(0.000281)$ \\
\hline \multirow[t]{2}{*}{ Sweet potato price } & 0.000493 & 0.000283 & 0.000674 \\
\hline & $(0.000300)$ & $(0.000332)$ & $(0.000578)$ \\
\hline \multirow[t]{2}{*}{ LT rainfall } & $0.00153 * * *$ & $0.00168^{* * *}$ & $0.00375^{* * *}$ \\
\hline & $(0.000464)$ & $(0.000561)$ & (0.000769) \\
\hline \multirow[t]{2}{*}{ 5-year rainfall } & $0.00318^{* *}$ & $-0.00537 * * *$ & $0.00664^{* *}$ \\
\hline & $(0.00154)$ & $(0.00201)$ & $(0.00258)$ \\
\hline \multirow[t]{2}{*}{ Planting season } & -0.000649 & $-0.0334 * * *$ & -0.0112 \\
\hline & $(0.0103)$ & $(0.0120)$ & $(0.0184)$ \\
\hline \multirow[t]{2}{*}{ Nutrient availability } & $0.121^{*}$ & 0.0942 & 0.0502 \\
\hline & $(0.0688)$ & $(0.0787)$ & $(0.124)$ \\
\hline \multirow[t]{2}{*}{ Constant } & $-3.501 * * *$ & $3.550 * *$ & $-9.966 * * *$ \\
\hline & $(1.247)$ & (1.687) & $(2.224)$ \\
\hline
\end{tabular}

Source: Authors. $\mathrm{N}=1045$. Robust standard errors in parentheses. $* * * \mathrm{p}<0.01,{ }^{*} \mathrm{p}<0.05,{ }^{*} \mathrm{p}<0.1$

Regression is second stage 2SLS for vitamin A diversity (R-squared not used). 
Table 7. Ordered Logit Regression, Impact of Growing Hybrid Seed on the Frequency of Consumption of Vitamin A-Fortified Food

\begin{tabular}{|c|c|c|}
\hline & Grow Hybrid $(0,1)$ & Scale of Hybrid Use $(\mathrm{kg})$ \\
\hline \multirow{2}{*}{ Hybrid seed use } & $0.277^{*}$ & 0.00133 \\
\hline & $(0.149)$ & $(0.00189)$ \\
\hline \multirow[t]{2}{*}{ Female headship } & 0.0488 & 0.0528 \\
\hline & $(0.173)$ & $(0.173)$ \\
\hline \multirow[t]{2}{*}{ Literacy } & $0.954 * * *$ & $0.992 * * *$ \\
\hline & $(0.255)$ & $(0.256)$ \\
\hline \multirow[t]{2}{*}{ Young adults } & 0.0304 & 0.0312 \\
\hline & $(0.0638)$ & $(0.0640)$ \\
\hline \multirow[t]{2}{*}{ Mature adults } & -0.0259 & -0.0361 \\
\hline & $(0.0522)$ & $(0.0541)$ \\
\hline \multirow[t]{2}{*}{ Older adults } & $-0.151 * *$ & $-0.155^{* *}$ \\
\hline & $(0.0702)$ & $(0.0706)$ \\
\hline \multirow[t]{2}{*}{ Land size } & 0.218 & 0.185 \\
\hline & $(0.194)$ & $(0.213)$ \\
\hline \multirow[t]{2}{*}{ Assets } & $0.152 * * *$ & $0.153 * * *$ \\
\hline & $(0.0551)$ & $(0.0549)$ \\
\hline \multirow[t]{2}{*}{ Cell } & $0.877 * * *$ & $0.909 * * *$ \\
\hline & $(0.147)$ & $(0.148)$ \\
\hline \multirow[t]{2}{*}{ Radio } & $0.489 * * *$ & $0.508 * * *$ \\
\hline & $(0.170)$ & $(0.169)$ \\
\hline \multirow[t]{2}{*}{ Distance to paved road } & $-5.30 \mathrm{e}-07$ & $-3.88 \mathrm{e}-07$ \\
\hline & $(1.50 \mathrm{e}-06)$ & $(1.50 \mathrm{e}-06)$ \\
\hline \multirow[t]{2}{*}{ Seed-to-grain price } & $0.0636 * * *$ & $0.0668 * * *$ \\
\hline & $(0.0182)$ & $(0.0185)$ \\
\hline \multirow[t]{2}{*}{ Bean price } & $3.69 \mathrm{e}-05$ & $4.23 \mathrm{e}-05$ \\
\hline & $(0.000101)$ & $(0.000101)$ \\
\hline \multirow[t]{2}{*}{ Cotton price } & $0.000607 * * *$ & $0.000581^{* * *}$ \\
\hline & $(0.000220)$ & $(0.000222)$ \\
\hline \multirow[t]{2}{*}{ Sweet potato price } & 0.000285 & 0.000309 \\
\hline & $(0.000442)$ & $(0.000446)$ \\
\hline \multirow[t]{2}{*}{ LT rainfall } & $0.00122 *$ & $0.00119^{*}$ \\
\hline & $(0.000666)$ & $(0.000669)$ \\
\hline \multirow[t]{2}{*}{ 5-year rainfall } & -0.00230 & -0.00192 \\
\hline & $(0.00203)$ & $(0.00201)$ \\
\hline \multirow[t]{2}{*}{ Planting season } & -0.000310 & -0.000496 \\
\hline & $(0.0151)$ & $(0.0152)$ \\
\hline \multirow[t]{2}{*}{ Nutrient availability } & 0.0398 & 0.0432 \\
\hline & $(0.0942)$ & $(0.0936)$ \\
\hline \multirow[t]{2}{*}{ Constant (cut 1) } & $5.165 * * *$ & $5.295 * * *$ \\
\hline & $(1.841)$ & $(1.844)$ \\
\hline \multirow[t]{2}{*}{ Constant (cut 2) } & $5.863 * * *$ & $5.991 * * *$ \\
\hline & (1.839) & $(1.842)$ \\
\hline Wald chi2(19) & 160.9 & 161.0 \\
\hline
\end{tabular}


suggesting these may be related to purchases with cash earnings. However, the distance to paved roads has no observable effect. The effect of higher long-term rainfall is positive.

\section{CONCLUSIONS}

Although much is known about maize production and also about household nutrition in Zambia, we are unaware of published studies that relate use of maize hybrids to dietary diversity other than the analysis conducted by Kumar in 1994. In this paper, we tested the impact of growing hybrids on the dietary diversity of smallholder farm families in maize-growing regions of Zambia. We interviewed women personally in a survey conducted in 2011.

We failed to reject the exogeneity of maize hybrid adoption when measured as a binary variable. We then estimated a sequence of dietary diversity equations (food group diversity, vitamin A diversity, and food frequency) with adoption (0-1) treated exogenously. However, we rejected the exogeneity of hybrid seed use when measured in terms of kilograms planted, or the extent of adoption. Our fourth dietary diversity equation, explaining the frequency of consumption of food fortified with vitamin A, was estimated with ordered logit regression.

Findings are robust across econometric models, although the overall statistical strength of the regressions and individual coefficients vary. Growing hybrid seed, whether measured as a binary variable or in terms of kilograms, has a powerful effect on the numbers of food groups consumed by household members in the preceding 24-hour reference period, as well as the number of food groups that are sources of vitamin A. This result continues to hold when the frequency of consumption from diverse food groups is considered, and is larger in the regressions employing the scale of hybrid seed use. 
Other major factors that positively influence dietary diversity include adult literacy, higher long-term rainfall and soil nutrient availability, total areas cultivated in both growing seasons, asset values, cell phone and radio ownership, and access to paved roads. These findings suggest that both production systems, which influence the diversity of crops produced and sold, and market access, which influences the foods a family has the potential to purchase, affect dietary diversity.

The major implication of this result is that diet diversity, consumption of vitamin Afortified products, and hybrid seed use are already positively interrelated among women in smallholder maize-growing households of Zambia. Related literature documents the close relationship often found between women's diets and the diets of their children. Based on our results, we conclude that in the case of smallholder farming in the major maize-producing regions of Zambia, hybrid seed use does not counteract dietary diversity.

Our findings are robust to econometric method and indicator: women interviewed in maize-growing households that plant hybrid seed have more diverse diets. These findings suggest that the Government of Zambia may continue to encourage the use of hybrid maize seed without sacrificing diet diversity. Stated more positively, reaching farm households who have not yet benefited from adopting hybrid maize could contribute to more diverse diets for women and children in rural Zambia.

\section{ACKNOWLEDGEMENTS}

The authors gratefully acknowledge the support of the Bill and Melinda Gates Foundation in funding this research. 


\section{REFERENCES}

Angrist, JD, and Krueger, AB (2001). Instrumental variables and the search for identification:

From supply and demand to natural experiments. Journal of Economic Perspectives 15 (4): 69-85.

Arimond, M, and Ruel, MT (2002) Progress in developing an infant and child feeding index: An example using the Ethiopia Demographic and Health Survey 2000. IFPRI FCND Discussion Paper 143. Washington, DC: International Food Policy Research Institute.

(2002) Dietary diversity is associated with child nutritional status: Evidence from 11 demographic and health surveys. Journal of Nutrition 134 (10): 2579-2585.

Arimond, M, Wiesmann, D, Becquey, E, Carriquiry, A, Daniels, MC, Deitchler, M, FanouFogny, N, Joseph,ML, Kennedy,G, Martin-Prevel,Y, and Elin Torheim, L (2010) Simple food group diversity indicators predict micronutrient adequacy of women's diets in 5 diverse, resource-poor settings. Journal of Nutrition 140: 2059S-2069S.

de Janvry, A, Fafchamps, M, and Sadoulet, E (1991) Peasant household behavior with missing markets: Some paradoxes explained. The Economic Journal 101: 1400-141.

Fiedler, JL, Zulu, R, Kabaghe, G, Lividini, K, Tehinse, J, and Bermudez, O (2012) Towards overcoming the nutrition information gap-induced impasse: Identifying Zambia's fortification policy options. Mimeo, Washington, DC: HarvestPlus.

FAO/IIASA/ISRIC/ISSCAS/JRC (Food and Agriculture Organization of the United Nations/ International Institute for Applied Systems Analysis/ISRIC-World Soil Information/Institute of Soil Science - Chinese Academy of Sciences/ Joint Research 
Centre of the European Commission). (2009) Harmonized World Soil Database (version 1.1). Rome, Italy; Laxenburg, Austria: FAO; IIASA.

Joshi, P.K., Gulati, A, Birthal, P.S. and Tewari, L. (2004). Diversification in South Asia: Patterns, Determinants and Policy Implications. Economic and Political Weekly. Vol. 39, No. 24 (June 12-18): 2457-2467.

Hamazakaza, P, Smale, M, and Kasalu, H (2013) The impact of hybrid maize on smallholder livelihoods in Zambia: Findings of a household survey in Katete, Mkushi, and Sinazongwe Districts. Working Paper 73. Lusaka, Zambia: Indaba Agricultural Policy Research Institute (IAPRI).

Heisey, PW, Smale, M (1995) Maize Technology in Malawi: A Green Revolution in the Making? CIMMYT Research Report No. 4. Mexico, D.F.: International Maize and Wheat Improvement Center (CIMMYT).

Heisey, PW, Morris, ML, Byerlee, D, and López-Pereira, M (1998) Economics of hybrid maize adoption. In: Maize Seed Industries in Developing Countries, Morris ML, editor. Boulder, CO, US: Lynne Rienner Publishers, Inc, pp 143-158.

Hijmans, RJ, Cameron, SE, Parra, JL, Jones, PG and Jarvis, A (2005) Very high resolution interpolated climate surfaces for global land areas. International Journal of Climatology 25: 1965-1978.

Hoddinott, J, and Yohannes, Y (2002) Dietary diversity as a household food security indicator. Washington, DC: Food and Nutrition Technical Assistance (FANTA) Project, Academy for Educational Development. 
Hotz, C, Chileshe, J, Siamusantu, W, Palaniappan, U, Kafwembe, E (2012) Vitamin A intake and infection are associated with plasma retinol among pre-school children in rural Zambia. Public Health Nutrition 15(9):1688-96.

Howard, J, and Mungoma, C (1997) Zambia's stop-and-go revolution. In: Africa's emerging maize revolution, D. Byerlee, C, and Eicher, CK, editors. Boulder, CO, US: Lynne Rienner Publishers, Inc, pp 45-61.

Kassie, GT, Erenstein,O, Mwangi, W, Setimela, P. and MacRobert, J (2013) Analysis of the maize seed industry in Southern Africa: Trends and implications. Agrekon 52: 104-127.

Kumar, SK (1994) Adoption of hybrid maize in Zambia: Effects on gender roles, food consumption and nutrition. Research Report 100. Washington, DC: International Food Policy Research Institute.

Langyintuo, AS, and Mungoma, C (2008) The effect of household wealth on the adoption of improved maize varieties in Zambia. Food Policy 33: 550-559.

Mason, N and Smale, M (2013) Impacts of subsidized hybrid seed on indicators of economic well-being among smallholder maize growers in Zambia. Agricultural Economics 44(6): in press.

Moursi, M, Arimond, M, Dewey, KG, Treche, S, Ruel, MT, and Delpeuch, F (2008) Dietary diversity is a good predictor of the micronutrient density of the diet of 6- to 23-month-old children in Madagascar. Journal of Nutrition 138: 2448-2453.

NFNC (National Food and Nutrition Commission)/University of Zambia/ MOST/CDC. (2004) Report of the National Survey to Evaluate the Impact of Vitamin A Interventions in Zambia in July and November 2003. Lusaka, Zambia. 
Nguyen, PH, Avula, R, Ruel, MT, Saha, KK, Ali,D, Tran, LM, Frongillo, EA, Menon, P. and Rawat, R (2013) Maternal and child dietary diversity are associated in Bangladesh, Vietnam, and Ethiopia. Journal of Nutrition 143: 1176-1183.

Ruel, MT (2002) Is dietary diversity an indicator of food security or dietary quality? A review of measurement issues and research needs. FCND Discussion Paper No. 140. Washington, DC: International Food Policy Research Institute.

_ (2003) Operationalizing dietary diversity: A review of measurement issues and research priorities. Journal of Nutrition 133: 3911S-3926S.

Schneider, U, Becker, A, Finger, P, Meyer-Christoffer, A, Rudolf, B, and Ziese, M (2011) GPCC full data reanalysis version 6.0 at $0.5^{\circ}$ : Monthly land-surface precipitation from rain-gauges built on GTS-based and historic data. DOI: 10.5676/DWD_GPCC/FD_M_V6_050.

Singh, I, Squire, L, and Strauss, J, eds. (1986) Agricultural household models: Extensions, applications and policy. Washington, DC; Baltimore, MD: The World Bank; Johns Hopkins University Press.

Smale, M, and Olwande, J, (2014). Demand for maize hybrids and hybrid change on smallholder farms in Kenya. Agricultural Economics.

Swindale, A, and Bilinsky, P (2006) Household dietary diversity score (HDDS) for measurement of household food access: Indicator guide (v.2). Washington, DC: Food and Nutrition Technical Assistance (FANTA) Project, Academy for Educational Development.

Van Dusen, ME and Taylor, JE (2005) Missing markets and crop biodiversity: Evidence from Mexico. Environment and Development Economics 10(4): 513-531. 
West, K. P. 2002. “Extent of Vitamin A Deficiency among Preschool Children and Women of Reproductive Age." Journal of Nutrition 132: 2857S-2866S.

Working Group on Infant and Young Child Feeding Indicators (2006) Developing and validating simple indicators of dietary quality and energy intake of infants and young children in developing countries: Summary of findings for analysis of 10 data sets. Washington, DC: Food and Nutrition Technical Assistance (FANTA) Project, Academy for Educational Development. 
Figure A.1: Distributions of Vitamin A Diversity Scores, by Reference Period
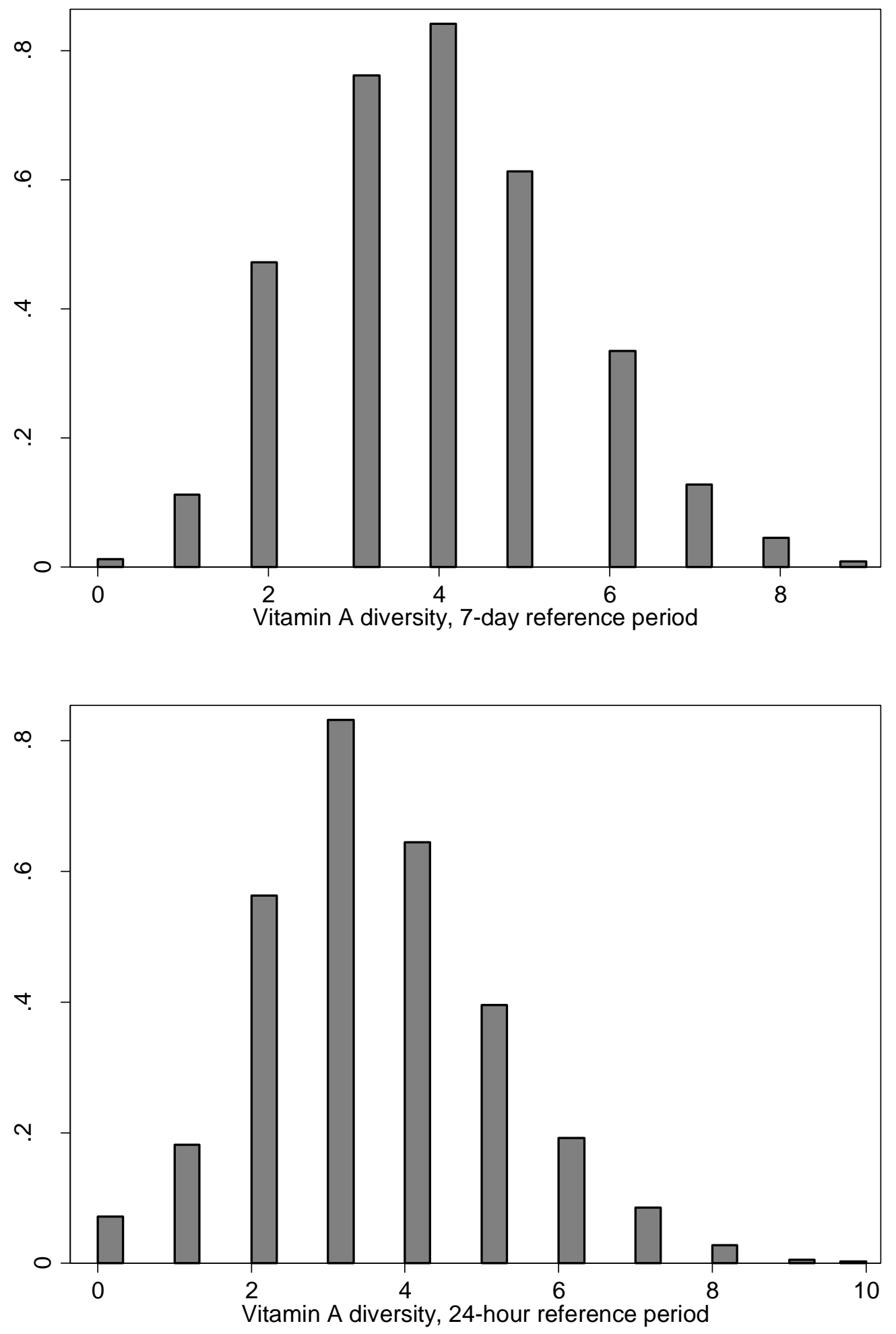
Table A.1. Food Groups as Elicited in Household Survey

Respondent should be the wife of the household head and/or mother of the household, otherwise respondent should be other female adult household member who is 15 years of age or older.

\begin{tabular}{|c|c|c|c|c|}
\hline & & $\begin{array}{c}\text { Did you consume [food } \\
\text { item] in the last } 24 \\
\text { hours? }\end{array}$ & $\begin{array}{l}\text { Did you consume [food } \\
\text { item] in the last } 7 \text { days? }\end{array}$ & $\begin{array}{l}\text { How many times in the last } \\
\text { seven days did you consume } \\
\text { [food item }] ?\end{array}$ \\
\hline & & $\begin{array}{c}1=\text { Yes }>>\text { IA4 } \\
2=\text { No }>>\text { IA3 } \\
-99=\text { Don't } \\
\text { know/remember }\end{array}$ & $\begin{array}{c}1=\text { Yes }>>\text { IA4 } \\
2=\text { No }>>\text { next item } \\
-99=\text { Don't } \\
\text { know/remember }\end{array}$ & Number of times \\
\hline 1 & Maize & & & \\
\hline 2 & Other cereals & & & \\
\hline 3 & Beans and other pulses (such as cowpeas, etc.) & & & \\
\hline 4 & Nuts and seeds & & & \\
\hline 5 & Sugar & & & \\
\hline 6 & Sweet potato, orange fleshed & & & \\
\hline 7 & $\begin{array}{l}\text { Other roots and tubers (Irish potatoes, cassava, white fleshed sweet } \\
\text { potato, etc.) }\end{array}$ & & & \\
\hline 8 & Fruits (mango, pineapple, guava, pawpaw, etc.) & & & \\
\hline 9 & Wild fruits & & & \\
\hline 10 & Eggs & & & \\
\hline 11 & Milk, cheese & & & \\
\hline 12 & Dark-green leafy vegetables & & & \\
\hline 13 & Other vegetables (pumpkin, tomatoes, etc.) & & & \\
\hline
\end{tabular}




\begin{tabular}{|l|l|l|l|l|}
\cline { 2 - 5 } 14 & Fish and other seafood (shrimp, crab, etc.) & & & \\
\hline 15 & Red meat (cow, goat, pig, sheep, pork, etc.) & & \\
\hline 16 & Animal liver, kidney, and other offals & & & \\
\hline 17 & Poultry (chicken, duck, etc.) & & \\
\hline 18 & Blue Band margarine (vitamin A fortified) & & & \\
\hline 19 & Fats and oils (butter, other margarine, soybean, mustard, ghee, etc.) & & & \\
\hline
\end{tabular}


Table A.2. Nutrient Availability-Factor Rating for Modal Crop and Land Use Type

\begin{tabular}{|c|c|c|c|c|}
\hline \multirow{2}{*}{$\begin{array}{c}\text { Diagnostic } \\
\text { Factor }\end{array}$} & \multicolumn{4}{|c|}{ Degree of Limitation } \\
\hline & Slight & Moderate & Severe & Very Severe \\
\hline $\begin{array}{l}\text { Organic } \text { carbon } \\
(\%)\end{array}$ & $\geq 1.0$ & $0.5-1.0$ & $0.25-0.5$ & 0.25 \\
\hline $\begin{array}{l}\text { Base } \quad \text { saturation } \\
(\%)\end{array}$ & $50-100$ & $35-50$ & $15-35$ & $<15$ \\
\hline Soil reaction $(\mathrm{pH})$ & $5.5-7.5$ & $5.0-5.5$ or $7.5-8.0$ & $\begin{array}{c}4.5-5.0 \text { or } 8.0- \\
8.4\end{array}$ & $\leq 4.5$ or $\geq 8.4$ \\
\hline
\end{tabular}

